\title{
DOES IDENTITY MATTER?
}

\author{
Lóránt Csink \\ Pázmány Péter Catholic University, Faculty of Legal and Political Sciences
}

\begin{abstract}
During Brexit campaign leave supporters reckoned that their sovereignty is priceless. They meant that Britain's status within or outside the European Union should not be decided upon economic reasons only. The campaign was successful and now the Kingdom is paying the price of her sovereignty. In Hungary in 2015 the government decided to ban shops to open on Sundays which was against the aspirations of both enterprises and consumers. The government found the measure so symbolic, so close to its identity that it did not respect any criticism. The government paid the political price of the unpopularity of the measure. Later on the government realised that the stake was too high and withdrew the piece of legislation. Such events clearly highlight that maintaining identity always has its price. Such price can be either economic or political. The question is if governments are ready to pay the price. It does not seem proper if mere economic and political expectations overrule symbolic issues. Neither it is acceptable if the government gives the nation's entire fortune for symbolic reasons. It must always be considered how much identity costs and if it is worth paying the price. The question can be answered upon the identity test that has two factors: first how important the issue is (how close it is to identity) and if the price of identity is proportionate to the economic, political price. The more important the issue is the greater price can be paid. And conversely, the greater the economic or political price is, the more cautious one should be. The present article sums up the most basic information on constitutional identity and analyses the factors of the identity of the Hungarian constitution, the Basic Law, with special attention to the contemporary identity debate. It argues that constitutional identity is not a strict and non-changing phenomenon but rather the procedure of continuous development.
\end{abstract}

Keywords: constitutionalism, identity, European Union and Member States

\section{ABOUT IDENTITY}

Identity is the collection of characteristics according to which a living entity or a thing can be differentiated from others. ${ }^{1}$ Identity is a defining part of personality; without identity you could not be distinguished from others, so you would not be the same person any longer. Moreover people can only partly form their own identity. As identity is given, one should neither show off, nor be ashamed of it.

In constitution theory the question arises if constitutions have identities and if they do, what makes their basic features. The question is important because the cultural identity of a society is not homogenous. People as members of society have different views on the meaning of life, role of the state, etc that makes impossible to define a constitutional identity that perfectly fits the iden-

1 DOMJÁN, K. A személyiség problémái a pszichológiában (Problems of Personality in Psychology). In GYÖRGY, G. (ed.): Pszichológia. Budapest: Nemzeti Tankönyvkiadó, 1974, p. 118. 
tity of all people. In other words: does constitutional identity not segregate people whose personal identity is different? The answer connects to the legitimacy of constitutions. Constitutions can only be legitimate if it accepts not only one view but, even if the constitution stands for a specific value, accepts that some people may stand for other values. Constitutions have to protect the minority opinion in this sense. ${ }^{2}$

Was it not better if the constitution contained no values at all? Not at all. A constitution is not only a legal document that contains the most fundamental regulations on human rights and state organisation. Yet it is a catalogue of principles and values on which the state and the society base. It is essential for a constitution to implement values and principles, as a result of which it is also essential for a constitution to have identity. Lack of identity is not equal to neutrality but to emptiness. Neither does neutrality mean the lack of values. ${ }^{3}$

This also explains why constitutions are different. At first sight, constitutions are very similar. Human rights are universally acknowledged, they are regulated in a similar content. All civilised constitutions declare rule of law, separation of powers, equality, popular sovereignty, etc. Although there are differences in the work of state administration, all countries have parliaments, judiciary, executive power and so on. Despite all similarities if you read several constitutions you may find an utterly different picture on the constitutions and on societies. Constitutions can be individualists or collectivists, social or capitalists, secular or religious. Such differences may not reveal from the provisions at first sight; they root in the different identity of the constitution.

One may conclude that all constitutions have identities. Obviously, the statement is a personification; not the legal text itself but the society (the nation) has identity that manifests in the constitution.

\section{HEREDITARY AND ACQUIRED PARTS OF IDENTITY}

When analysing the identity of a constitution, one of its peculiarity must not be forgotten: it keeps changing. Some parts of identity are hereditary, genetically determined, while some other parts are acquired, formed by external effects i.e. the effects of the social environment. For sociologists and psychologists it is an everlasting debate to what proportion they determine identity but they mostly agree that both have roles in stipulating identity.

The situation is much the same at the case of constitutions. Hereditary elements are the ones that are explicitly stipulated in the constitution. They are not affected by jurisprudence or social behaviour, they manifest the will of the Parliament (the creator of the constitution) only. As politicians decide on the constitutional text, it is a political decision which values to base on. Theoretically, the creator of the constitution is free to implement any value to the constitution, there is no constitutional limit for a constitution. It is an entirely different issue if it is wise to implement whatsoever values to the constitutional text or if it can be successful in the end.

Hereditary elements always play a great role in constitutional identity. Jurisprudence must respect theological interpretation, i.e. the constitutional aim beyond the provision. However, the con-

2 KUKORELLI, I. Magyarországot saját alkotmánya nélkül kormányozni nem lehet (Hungary cannot be Governed without Her Own Constitution). Budapest: Méry Ratio, 2014, p. 167.

3 SCHANDA, B. Keresztény vagy semleges? Az Alaptörvény identitásának a kérdése (Christian or Neutral? On the Identity of the Basic Law). In Magyar Jog, 2015/3, p. 131. 
stitution is more than the will of the constitution-maker. Constitutions are not in vacuum. They strongly connect to the society: the constitution stipulates the basic rules of the society on the one hand and society and politics form the constitution itself on the other. Moreover, the constitution is interdependent to jurisprudence, because "the constitution is what the judges say it is". ${ }^{4}$ As soon as the constitution enters into force, it became affected by its environment. Jurisprudence interprets the text, giving special meanings for some provisions.

State organs, the society apply the constitution during which they emphasise some provisions while neglect some others. All such factors form the constitution, during its lifetime the same provisions can have very different interpretations. A good example for that is the US Constitution. Now it has a very different consideration on equality, property, human beings than it had at the time of its creation in 1787 . As it is very difficult to pass amendments to the constitutional text, it developed mostly by judicial interpretation. Consequently, the identity of the constitution is formed by some factors other than the will of the parliament (acquired factors).

Acquired and hereditary factors often compete each other and their combination results in identity. This is also the case concerning constitutional identity. Judicial interpretation, social law-application influence the meaning of the text. This phenomenon is absolutely natural. The change of the meaning of the text signs that the constitution is a living entity; reacts to the influences of its surroundings.

\section{PRACTICAL EXPERIENCE: IDENTITY OF THE HUNGARIAN CONSTITUTION}

When comparing the Basic Law (the current constitution of Hungary) to the previous Constitution, one can easily find rhetoric discontinuity. ${ }^{5}$ The Basic Law has a different view on human beings, society and state from the previous Constitution. Little does the difference manifest in the detailed provisions of the Basic Law. Instead, the entire picture is different. The spectacular and debated provisions of the Basic Law (protection of foetal life, marriage is only for people of opposite sex, constitutional aim may be ground for limiting fundamental right) are not new elements but were previously manifested in older jurisprudence of the Constitutional Court. Yet the Basic Law bases on a very different philosophy.

In 2010 and 2011, at the time of the creation of the Basic Law, the constitution maker had an utterly different moral background than in 1989, at the time of the political transition. When the republic was proclaimed, the constitution-maker intended everything but socialism. It considered that the communitarian approach is an obstacle for people to be independent. The constitution that time based on capitalism and individualism to free the people from socialism. Twenty years thereafter when moral and economic crisis emerged nationally and globally, the role of the community enlarged. Therefore, the Basic Law roots much more in collectivism and solidarity than in individualism. ${ }^{6}$

4 HUGHES, C. E. Speech before the Chamber of Commerce. New York: Elmira (3 May 1907); published in Addresses and Papers of Charles Evans Hughes, Governor of New York, 1906-1908 (1908), p. 139.

5 SONNEVEND, P. et al. The Constitution as an Instrument of Everyday Party Politics. In: BOGDANDY, A., SONNEVEND, P. (ed.): Constitutional Crisis in the European Constitutional Area. Oxford, Portland : Hart Publishing, 2015, p. 65.

6 ABLONCZY, B. Az alkotmány nyomában (In Search of the Constitution). Budapest : Elektromédia, 2011 , p. 87. 
To evaluate the entire Basic Law one would say that it emphasises moral considerations to reach social justice, instead of formal rule of law. Remarkably, the Basic Law brings closer the cultural nation to the political one, cultural and religious symbols and respect of tradition.

According to the hereditary factors, the constitutional identity of the Basic Law seems to be very different from the identity of the previous constitution.

Among the acquired factors one should consider how stable the Basic Law is politically. Stability is a value in itself. The frequent or continuous change of the social order endangers security and certainty. When making a constitution the Parliament has to set the base of the society, should define norms and principles in a long run.

Besides stability, the constitution should be flexible, too. Different ages, ideas and values should find their place in the constitution. If the Parliament reveals the majority opinion only, people in minority intend to change the constitution and reveal their own opinion as majority one. Revealing both majority and minority opinion is neither only a gesture towards others, nor it is because of pluralism but also for the stability of the constitution.

As for constitutions, stability has two aspects. On the one hand, social stability means that the constitution contains principles that meet the acceptance of a great part of the society. No constitution will be applied if it neglects the particular social relations. On the other hand, constitutions should be politically stable, too. Constitutions are stable if different governments can implement their various policies within the frames of the constitution. Constitutions can be successful if most political forces accept them as the common "rule of the game". Otherwise the stake of the election is not only to define policies in the next couple of years but to change or to maintain the constitution. Yet this results in a permanent constitution-making and the society will miss its solid ground.

Considering such aspect, one may conclude that the political influences towards the Basic Law are not favourable. In the first six years of its application the Basic Law was amended seven times (five of them in the first two years), moreover several amendments were because of daily political issues. Manifesting daily political battles in the Basic Law does not serve stability.

Besides politics, constitutional adjudication also has an impact on the Basic Law. How does the Basic Law prevail in practice? The Constitutional Court has obviously adopted the new provision of the Basic Law but has not (or just partly) adopted its new value content. The Constitutional Court upheld its former jurisprudence, due to the continuity of content between the old and the new constitution. "The Constitutional Court's interpretation of certain institutions, principles and provisions can be found in its decisions. The Constitutional Court's statements made on the fundamental values, human rights and freedoms and on the constitutional institutions that have not been changed fundamentally by the Fundamental Law remain valid. The principal statements expressed in the Constitutional Court's decisions based on the previous Constitution shall remain applicable as appropriate also in the decisions interpreting the Fundamental Law. However, the statements made in the decisions based on the previous Constitution cannot be taken over automatically without any examination; the provisions of the previous Constitution and of the Fundamental Law have to be compared and carefully weighed. If the comparison results in establishing that the constitutional regulation has not been changed or it is essentially similar to the previous one, then the interpretation can be transposed. On the other hand, when the contents of the provisions of the previous Constitution and of the Fundamental Law are the same, the reasoning is required for not taking into account the legal principles presented in the former decisions of the Constitutional Court, and not in the case of applying them".

$7 \quad 22 / 2012$ (V. 11.) CC. 
The Fourth Amendment to the Basic Law proved to be an interesting novelty concerning continuity. It states: "The decisions of the Constitutional Court made prior to the entry into force of the Fundamental Law are repealed. This provision shall be without prejudice to the legal effects produced by those decisions." Still, against the intention of the Parliament, the Constitutional Court upheld the use of its previous decisions. Admittedly, their use is not automatic but needs reasoning. With using the former jurisprudence the Constitutional Court also formulates the identity of the Basic Law.

\section{IDENTITY ISSUES IN CONTEMPORARY CONSTITUTION-MAKING: THE SEVENTH AMENDMENT TO THE BASIC LAW}

Migration issue has become a great and symbolic quarrel between the European Union and some member states including Hungary. As Hungary is rather repulsive in accepting refugees, the European Union blames the state with infringing human rights and breeching international obligations. On the contrary, Hungary's position is that the European Union violates the nation's sovereignty that includes the decision on who to welcome to the country.

In this debate identity is a frequently quoted reference points. The European Union reckons that rule of law and respect of human rights are identical values; values whom Hungary does not respect. Hungary considers that national identity is a kind of essential core of the constitution, a part of national sovereignty that not even EU law can touch. In this debate the Parliament adopted the Seventh Amendment to the Basic Law that introduced important novelties concerning identity. The preamble states that "The protection of our identity is the state's basic obligation" and among the Fundaments the Basic Law stipulates that "All state bodies are obliged to protect constitutional identity and Christian culture" [Art. R (4)]. It also reckons that "Participation in the European Union may not infringe Hungary's territorial integrity, population, form of state, state structure" [Art. E]. Although the amendment intended to create the constitutional base of not accepting asylum seekers as the EU Decision requested, it is unlikely to reach the target. Not only because member states cannot refer to their own constitutions but also because temporarily hosting asylum seekers does not seem to be an intervention to Hungary's population. Consequently it is not the infringement of identity.

At present, constitutional identity seems to concur the identity of the European Union. But is it really the case? Interpreting the constitution the Constitutional Court stated that the elements of identity are especially separation of powers, rule of law, dignity, human rights, achievements of

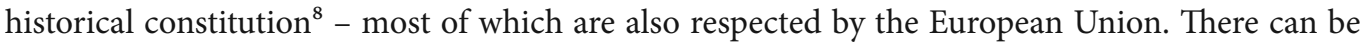
political and constitutional debates, misunderstanding between the Union and a member state. Yet such debates do not mean that identities cannot be harmonised.

\section{TO CONCLUDE}

Having regard the seven years that have passed since the adoption of the Basic Law, one may conclude that the identity of the Basic Law is formed by various factors. The acquired factors are different

$8 \quad 26 / 2012$ (V. 18.) CC 
from the hereditary ones. Such difference requires the dialogue among the institutions forming the identity of the Basic Law. The language of the dialogue is constitutional law; this is the language constitutional lawyers speak and understand even if they disagree.

Does the Basic Law have identity? Certainly it does. Its present identity is not the one it had at the time of its creation but it is not problematic at all. If it were the same it would mean that the Basic Law does not react to the influences of its environment, yet this is the sign of life. The constitutionmaker has only a small impact on such change. Identity should not be an obstacle of any change; instead, the constitution must be ready to change. Yet the constitutional identity should not be changed for light causes; it has to preserve what is worth preserving.

\section{Bibliography:}

ABLONCZY, B: Az alkotmány nyomában (In Search of the Constitution). Budapest : Elektromédia, 2011.

DOMJÁN, K. A személyiség problémái a pszichológiában (Problems of Personality in Psychology). In GYÖRGY, G. (ed.): Pszichológia. Budapest : Nemzeti Tankönyvkiadó, 1974.

HUGHES, C. E. Speech before the Chamber of Commerce. New York: Elmira (3 May 1907); published in Addresses and Papers of Charles Evans Hughes, Governor of New York, 1906-1908 (1908).

KUKORELLI, I. Magyarországot saját alkotmánya nélkül kormányozni nem lehet (Hungary cannot be Governed without Her Own Constitution). Budapest : Méry Ratio, 2014.

SCHANDA, B. Keresztény vagy semleges? Az Alaptörvény identitásának a kérdése (Christian or Neutral? On the Identity of the Basic Law). In Magyar Jog, 2015/3.

SONNEVEND, $\mathrm{P}$ et al. The Constitution as an Instrument of Everyday Party Politics. In : BOGDANDY, A., SONNEVEND, P. (ed.): Constitutional Crisis in the European Constitutional Area. Oxford, Portland : Hart Publishing, 2015.

\section{Contact information:}

Dr. Csink Lóránt, PhD, Dr. habil.

csink.lorant@jak.ppke.hu

Pázmány Péter Catholic University

Faculty of Legal and Political Sciences

H-1088 Budapest

Szentkirályi u. 28-30

Hungary 